\title{
PERANAN DAN KEDUDUKAN TENTARA NASIONAL INDONESIA (TNI) DI DALAM RANCANGAN UNDANG-UNDANG KEAMANAN NASIONAL DI TINJAU DARI PERSPEKTIF POLITIK HUKUM DI INDONESIA
}

\author{
Munsharif Abdul Chalim, Faisal Farhan \\ Dosen Fakultas Hukum UNISSULA \\ munsharifac@yahoo.com
}

\begin{abstract}
The formation of the armed forces in modern States intended to protect and defend the sovereignty of the State and the Nation State. But in reality, there are some inherent in expanding the role of the armed forces. The research method using normative juridical approach with The data collection methods focus on literature study materials secondary law. The results obtained are 1) The nature of national security are all efforts quickly, gradual and integrated by empowering all national forces to create security and stability through a system of national security, national security objectives, aims to create a safe condition of the nation and the Unitary State of the Republic of Indonesia physically and psychic each individual citizen, the people, the government and the State, in order to protect national interests, and delivery functions of national security is to: Establish, maintain, and develop a system of national security as a comprehensive, integrated, focused and realize all areas of national jurisdiction as a unified national security. 2) Politics of law contained in the preparation of a draft law of national security The main objective is to realize a safe condition of the nation and the State unitary Republic of Indonesia physically and psychologically every individual citizen, the people, the government and the State, in order to protect national interests.
\end{abstract}

Keywords: the role and position of TNI, The National Security Act, Law Politics

\begin{abstract}
Abstrak
Pembentukan angkatan bersenjata di Negara-Negara modern ditujukan untuk melindungi dan mempertahankan kedaulatan Negara dan Bangsa suatu Negara. Namun kenyataannya, terdapat beberapa perluasan peran yang melekat pada angkatan bersenjata tersebut. Metode penelitian menggunakan Pendekatan Yuridis Normatif dengan Metode Pengumpulan Datanya fokus pada Studi Kepustakaan bahan-bahan hukum sekunder. Hasil penelitian yang diperoleh yaitu 1) Hakikat keamanan nasional merupakan segala upaya secara cepat, bertahap dan terpadu dengan memberdayakan seluruh kekuatan nasional untuk menciptakan stabilitas keamanan melalui suatu sistem keamanan nasional, tujuan keamanan nasional bertujuan untuk mewujudkan kondisi aman bangsa dan Negara kesatuan Republik Indonesia secara fisik dan psikis setiap individu warga Negara, masyarakat, pemerintah dan Negara, dalam rangka melindungi kepentingan nasional, dan fungsi penyelenggaraan keamanan nasional adalah untuk : Membangun, memelihara, dan mengembangkan sistem keamanan nasional secara menyeluruh, terpadu, dan terarah, mewujudkan seluruh wilayah yurisdiksi nasional sebagai suatu kesatuan keamanan nasional. 2) Politik hukum yang terkandung didalam penyusunan rancangan undang-undang keamanan nasional mempunyai tujuan utama yaitu mewujudkan kondisi aman bangsa dan Negara kesatuan Republik Indonesia secara fisik dan psikis setiap individu warga Negara, masyarakat, pemerintah dan Negara, dalam rangka melindungi kepentingan nasional.

Kata kunci: Peranan dan Kedudukan TNI, Undang-undang keamanan Nasional, Politik Hukum
\end{abstract}




\section{A. PENDAHULUAN}

Tentara Nasional Indonesia (TNI) merupakan bagian dari masyarakat umum yang dipersiapkan secara khusus untuk melaksanakan tugas pembelaan negara dan bangsa, serta memelihara pertahanan dan keamanan Nasional. ${ }^{1}$

Seperti kita ketahui bahawa saat ini bangsa Indonesia sedang memasuki suatu masa transisi, suatu masa di mana kita tengah berubah atau beralih dari suatu era yang orang menyatakan itu sebagai era ototarian kepada era demokrasi, dan perubahan seperti itu memang masih banyak ketidakpastian. Namun demikian ada satu hal yang sudah pasti bahwa perubahan tersebut tidaklah mengubah tugas dan tanggung jawab TNI selaku alat Negara bidang pertahanan dan keamanan, serta tidak mengubah sikap dan perilaku prajurit TNI yang harus senantiasa mengayomi masyarakat.

Bahawa kalau pada era yang lalu TNI melaksanakan tugas bukan hanya di bidang pertahanan tetapi juga di bidang sosial politik, maka setelah kita memasuki era reformasi, TNI segera menempatkan posisinya yang tepat sesuai dengan tatanan Negara demokrasi. Peran sosial politik telah kita tinggalkan dan kita hanya berkonsentrasi di bidang pertahanan dan keamanan negara, kedepannya bisa jadi membantu memelihara keamanan dan ketertiban masyarakat dalam rangka membangun tugas Polri. ${ }^{2}$

Berakhirnya perang dingin dan merebaknya demokrasi baru telah menghubungkan optimisme mengenai hubungan sipil-militer di masa depan. Tetapi mewujudkan optimisme ini tidak semudah mengembalikan telapak tangan. Kontrol sipil obyektif atas militer, yang menurut Samuel Huntington merupakan salah satu syarat dari Negara demokrasi yang baik sulit diimplementasikan dengan segera, baik itu di masa perang maupun di masa damai.

1 Faisal Farhan, Skripsi tentang "Tindak Pidana Disersi Ditinjau Dari Perspektif Hukum Pidana Militer", Universitas Pasundan Fakultas Hukum, Bandung, 2011, hlm.1.

2 Jendral TNI Endriartono Sutarto, Kewajiban Prajurit Mengabdi Kepada Bangsa, Pusat Penerangan TNI, Desember 2005, hlm. 21 s.d 22
Hal ini dimungkinkan karena otoritas sipil belum mampu menerapkan kontrol yang kuat atas kebijakan militer dan pengambilan keputusan. Apalagi Negara di bangun sebagai institusi untuk memelihara eksistensi pertahanan dan keamanan nasional.Oleh karena itu pembentukan angkatan bersenjata di Negara-Negara modern ditujukan untuk melindungi dan mempertahankan kedaulatan Negara dan Bangsa suatu Negara. Namun kenyataannya, teradapat beberapa perluasan peran yang melekat pada angkatan berenjata tersebut. Perluasan ini dengan ideografis dan perkembangan suatu negara. Secara umum dapat diartikan bahwa pengaruh militer dengan multi fungsinya dalam memelihara keamanan nasional lebih disebabkan sejarah perjuangan Bangsa dan Negara Indonesia. ${ }^{3}$

Untuk menipis ambisi Menteri Pertahanan yang bakal menata ulang tentang Pertahanan dan Keamanan Negara melalui Rancangan Undang-undang Keamanan Nasional yang katanya peraturan perundangundangan yang ada tidak mencukupi untuk dapat secara efektif digunakan dalam penyelengaraan Keamanan Nasional sehingga perlu dirubah tanpa evaluasi. Agar sistem hukum Nasional tidak menjadi carut marut solusi yang terbaik adalah membatalkan keberadaan Rancangan Undang-undang Keamanan Nasional.

Alasannya, Rancangan Undangundang tersebut tidak mencantumkan filsafat hukum yaitu Pancasila serta mengabaikan UUD 1945 sebagai sumber hukum sebagaimana digariskan Undangundang Nomor 10 Tahun 2004 tentang Pembentukan Peraturan Perundangundangan. Ditambah adanya tumpang tindih kewenangan, lebih mengutamakan supremasi power ketimbang supremasi hukum bisa menimbulkan kesewenang-wenangan otoriter. Ironisnya, dilema kontroversi hukum ini pada ahkirnya bermuara ke Mahkamah Konstitusi untuk diajukan Judicial Review.

Menteri Pertahanan akan menata ulang tentang Pertahanan dan Keamanan

3 Syamsul Maarif, 2011, Militer Dalam Parlemen 19602004, Prenada, hlm 1-2. 
Negara melalui Rancangan Undang-undang Keamanan Nasional yang disinyalir bahwa peraturan perundang-undangan yang ada belum mencukupi untuk dapat secara efektif digunakan dalam penyelengaraan Keamanan Nasional sehingga perlu dirubah tanpa evaluasi. Agar sistem hukum Nasional tidak tumpang tindih maka solusi yang terbaik adakah dengan membatalkan keberadaan Rancangan Undang-undang Keamanan Nasional. ${ }^{4}$

Menurut Kemhan, dalam praktek kenegaraan terdapat sejumlah aktor sehingga penyelenggaraan keamanan nasional perlu diatur dalam suatu mekanisme keterpaduan yang mengakomodir seluruh aspek sehingga dapat mencapai hasil yang optimal perlu disinergikan seluruh potensi Bangsa disegala bidang baik aparat keamanan, penegak hukum, lembaga pemerintahan, TNI dan seluruh lapisan masyarakat dalam menciptakan keamanan nasional. Keinginan ini sudah diamanatkan dalam Pasal 2 dan Pasal 3 ayat (1) dan ayat (2) Undang-undang Nomor 2 Tahun 2002 tentang Polri, jika TNI dilibatkan maka akan jadi deteren. ${ }^{5}$

Dibawah ini akan dipaparkan mengenai rumusan dan maknanya tentang kemanan nasional. ${ }^{6}$ Tap VII/ MPR/ 2000, mengamanatkan lewat Bab II tentang Kepolisian Negara Republik Indonesia dalam pasal 6 ditegaskan ; tentang peran Kepolisian Negara Republik Indonesia :

1) Kepolisian Negara Republik Indonesia merupakan alat negara yang berperan dalam memelihara keamanan dan ketertiban masyarakat, menegakkan hukum, memberikan pengayoman, dan pelayanan kepada masyarakat. ${ }^{7}$

$4 \mathrm{lbid}, \mathrm{hlm} 5$.

5 Ibid, hlm. 7.

6 Ibid. Kiriman Surat POLRI Ke Presiden Replublik Indonesia tentang Kontroversi dan Fenomena yang timbul dalam Rancangan Undang-undang Keamanan Nasional, Dikutip dari www.google. com-detiknews.com, pada tanggal 12 Desember 2013.

7 Di Kutip dari www.google.com, Peraturan Perundanga-undangan Di Indonesia. pada tanggal 12 Desember 2013.
Berkaitan dengan Ketetapan MPR itu, secara rinci Undang-undang No 2 tahun 2002 dalam Bab I Ketentuan Umum pasal 1 ayat (6) menjelaskan ;

Keamanan dalam negeri adalah suatu keadaan yang ditandai dengan terjaminnya keamanan dan ketertiban masyarakat, tertib dan tegaknya hukum, serta terselenggaranya perlindungan, pengayoman, dan pelayanan kepada masyarakat.

Sementara itu, wewenang Polri untuk penanganan Keamanan Dalam Negeri diamanatkan pasal 4 Undang - undang Nomor. 2 Tahun 2002 ;

Kepolisian Negara Republik Indonesia bertujuan untuk mewujudkan keamanan dalam negeri yang meliputi terpeliharanya keamanan dan ketertiban masyarakat, tertib dan tegaknya hukum, terselenggaranya perlindungan, pengayoman, dan ketentraman masyarakat dengan menjunjung tinggi hak asasi manusia. ${ }^{8}$

Fenomena yang ada saat ini adalah bahwa sejak pemisahan institusi TNI dan Polri pada tanggal 1 April 1999 yang dipertegas melalui TAP MPR/MPRRI/ $\mathrm{VI} / 2000$ tentang pemisahan TNI dan Polri serta TAP MPR/MPR-RI/VII/2000 tentang Peran dan Fungsi TNI dan Polri persoalan penanganan masalah keamanan nasional/ keamanan Negara menghadapi kendala yang serius yang berimplikasi pada pelaksanaan tugas-tugas institusi yang berperan dalam melaksanakan sitem keamanan nasional yang telah ditetapkan melalui peraturan perundang-undangan. Dahulu ketika Institusi TNI dan Polri masih berada dalam satu wadah yaitu ABRI tugas-tugas keamanan nasional diperankan dengan baik oleh kedua institusi tersebut dalam arti ada harmonisasi dalam melaksanakan tugas karena dahulu tidak ada pemisahan antara tugas pertahanan dan keamanan.

Padahal apabila kita cermati dengan seksama munculnya permasalahan

8 lbid. www.google.com, Peraturan Perundangundangan Di Indonesia. Dikutip pada tanggal 12 Desember 2013. 
dibidang keamanan nasional ini bermuara dari keluarnya kedua TAP MPR tersebut diatas.Mengapa produk hukum yang dibuat justru menimbulkan permasalahan.Bukankah Hukum dibuat untuk menjawab persoalan. Berdasarkan pemaparan latar belakang diatas yang didasari pada fenomena-fenomena yang terdapat didalam Rancanangan Undangundang Keamanan Nasional.

Berdasarkan uraian yang dikemukakan diatas, maka dapat dirumuskan beberapa masalah dalam usulan penelitian ini, adalah sebagai berikut:

1. Bagaimana hakikat, tujuan, dan fungsi TNI didalam Rancangan Undangundang Keamanan Nasional?

2. Politik hukum apa yang digunakan dalam kaitannya tentang peranan dan kedudukan TNI di dalam Rancangan Undang-undang Keamanan Nasional?

\section{B. METODE PENELITIAN}

Metode penelitian yang dipakai dalam penelitian ini menggunakan metode yuridis normatif. Dalam penelitian hukum normatif, penelitian dilakukan dengan cara meneliti bahan pustaka atau data sekunder saja, sedangkan dalam penelitian hukum sosiologis penelitian dilakukan dengan meneliti data primer yang diperoleh langsung dari masyarakat (data dasar) ${ }^{9}$.

Spesifikasi penelitian ini adalah termasuk penelitian deskriptif analitis, yaitu menggambarkan peraturan perundangundangan yang berlaku dan dikaitkan dengan teori-teori hukum dan segala sesuatu yang berkaitan dengan kebijakan penegakan hukum pidana pidana dan penanggulangan money laundering dalam rangka pembaharuan hukum pidana di Indonesia

\section{HASIL PENELITIAN DAN PEMBAHASAN}

1. Hakikat, Tujuan, Dan Fungsi TNI Didalam Rancangan Undang-undang Keamnan Nasional

Hakikat keamanan nasional merupakan segala upaya secara

9 Peter Mahmud Marzuki, 2010, Penelitian Hukum, Kencana, Jakarta, hIm. 35. cepat, bertahap dan terpadu dengan memberdayakan seluruh kekuatan nasional untuk menciptakan stabilitas keamanan melalui suatu sistem keamanan nasional.(Pasal 2 Rancangan Undangundang Keamanan Nasional, Pembahasan Tanggal 16 Oktober 2012). ${ }^{10}$

Tujuan keamanan nasional bertujuan untuk mewujudkan kondisi aman bangsa dan Negara kesatuan Republik Indonesia secara fisik dan psikis setiap individu warga Negara, masyarakat, pemerintah dan Negara, dalam rangka melindungi kepentingan nasional (Pasal 3 Rancangan Undang-undang Keamanan Nasional, Pembahasan Tanggal 16 Oktober 2012). ${ }^{11}$

(Pasal 4 Rancangan Undangundang Keamanan Nasional, Pembahasan Tanggal 16 Oktober 2012). Fungsi penyelenggaraan keamanan nasional adalah untuk:

a. Membangun, memelihara, dan mengembangkan sistem keamanan nasional secara menyeluruh, terpadu, dan terarah;

b. Mewujudkan seluruh wilayah yurisdiksi nasional sebagai suatu kesatuan keamanan nasional;

c. Memelihara dan meningkatkan stabilitas keamanan nasional melalui tahapan pencegahan dini, peringatan dini, penindakan dini, penanggulangan, dan pemulihan; dan

d. Menunjang dan mendukung terwujudnya perdamaian dan keamanan regional serta internasional. ${ }^{12}$

TNI berperan sebagai alat Negara di bidang pertahanan yang dalam menjalankan tugasnya berdasarkan kebijakan dan keputusan politik Negara, hal ini tertuang di dalam Pasal 5 Undang

10 Hasil Rapat 16 Oktober 2012, Rancngan Undangundang Keamanan Nasional, Komisi III DPR RI, Op.Cit. hlm. 3.

11 Ibid, hlm. 3.

12 Ibid, hlm. 4. 
- undang No. 34 Tahun 2004 tentang TNI. ${ }^{13}$

Sedangkan didalam Pasal 6 Undang - undang No. 34 Tahun 2004 tentang TNI, fungsi TNI yaitu :

1) $\mathrm{TNI}$, sebagai alat pertahanan negara, berfungsi sebagai:

a. penangkal terhadap setiap bentuk ancaman militer dan ancaman bersenjata dari luar dan dalam negeri terhadap kedaulatan, keutuhan wilayah, dan keselamatan bangsa;

b. penindak terhadap setiap bentuk ancaman sebagaimana dimaksud pada ayat (1) huruf a; dan

c. pemulih terhadap kondisi keamanan negara yang terganggu akibat kekacauan keamanan.

2) Dalam melaksanakan fungsi sebagaimana dimaksud pada ayat (1), TNI merupakan komponen utama sistem pertahanan negara. ${ }^{14}$

TNI bertujuan untuk melaksanakan kebijakan pertahanan Negara untuk menegakkan kedaulatan negara, mempertahankan keutuhan wilayah dan melindungi keselamatan bangsa, menjalankan operasi militer untuk perang dan operasi militer selain perang, serta ikut secara aktif dalam tugas pemeliharaan perdamaian regional dan internasional. ${ }^{15}$

Undang-undang yang ada pada saat ini, baik undang-undang tentang TNI, Polri, maupun Undang - undang Pertahanan memang tidak satu pun yang secara langsung membahas mengenai arti "Kemanan Nasional".Walaupun terdapat beberapa ketumpang-tindihan (grey area), namun sesungguhnya tidak sedikit pun mengurangi arti dari tugas dan peran baik itu TNI

13 Undang-undang No. 34 Tahun 2004 Tentang TNI, Fungsi dan Tujuan TNI, Mabes TNI, Jakarta, hlm. 4. $14 \mathrm{lbid}, \mathrm{hlm} .5$.

15 Endriantono Sutanto, Jati Diri TNI, Mabes TNI, Cilangkap Jakarta, hlm. 20. maupun Polri.Pada pembahasan Undang-undang No.2 Tahun 2002 dan Undang-undang No.34 Tahun 2004, dapat dilihat secara jelas mengenai tugas, fungsi, dan peran dari TNI maupun Polri.Dan disana juga terlihat ada dimensi yang berbeda namun saling terkait antara tugas dan peran dari TNI dan Polri, sehingga yang sesungguhnya diperlukan adalah bentuk kerjasama dan koordinasi sehingga tugas-tugas TNI dan Polri dapat dilaksanakan dengan baik dalam bingkai kebersamaan. ${ }^{16}$

Peran dan Kedudukan TNI didalam Undang-undang No. 34 Tahun 2004, peran TNI berperan sebagai alat negara dibidang pertahanan yang dalam menjalankan tugasnya berdasarkan kebijakan dan keputusan politik Negara, sedangkan Fungsinya. ${ }^{17}$

TNI sebagai alat pertahanan negara, berfungsi sebagai, penangkal terhadap setiap bentuk ancaman militer dan ancaman bersenjata dari luar dan dalam negeri terhadap kedaulatan, keutuhan wilayah, dan keselamatan bangsa, Penindak terhadap setiap bentuk ancaman sebagaimana dimaksud pada ayat (1) huruf a, dan pemulih terhadap kondisi keamanan negara yang terganggu akibat kekacauan keamanan. ${ }^{18}$

Dalam melaksanakan fungsi sebagaimana dimaksud pada ayat (1), TNI merupakan komponen utama sistem pertahanan negara. TNI memiliki tugas pokok (1) Tugas pokok TNI adalah menegakkan kedaulatan negara, mempertahankan keutuhan wilayah Negara Kesatuan Republik Indonesia yang berdasarkan Pancasila dan UndangUndang Dasar Negara Republik Indonesia Tahun 1945, serta melindungi segenap

16 Jurnal Mabes TNI, Efektivitas Undang-undang TNI \& POLRI Di Indonesia, Mabes TNI, Cilangkap Jakarta, hlm 10.

17 Undang-undang No. 34 Tahun 2004 Tentang TNI, Fungsi dan Tujuan TNI, Mabes TNI, Jakarta, Op.Cit. hlm. 6.

$18 \mathrm{lbid}, \mathrm{hlm} .7$. 
bangsa dan seluruh tumpah darah Indonesia dari ancaman dan gangguan terhadap keutuhan bangsa dan negara.

Tentara Nasional Indonesia (TNI) menyatakan, tidak berkeberatan dengan rencana Departemen Pertahanan (Dephan) mengajukan Rancangan Undang-Undang (RUU) Keamanan Nasional (Kamnas) terkait dengan peranan dan kedudukan TNI didalam Rancangan Undang-undang tersebut. Sepanjang itu demi kepentingan pertahanan dan keamanan nasional yang lebih komprehensif dan optimal demi utuhnya Negara Kesatuan Republik Indonesia (NKRI), maka TNI tidak merasa harus keberatan terkait dengan peranan dan kedudukannya didalam Rancangan Undang-undang tersebut. TNI akan tetap menjalankan peran dan fungsinya sesuai ketentuan dan aturan yang berlaku, yakni Undang-undang No.34 Tahun 2004 tentang TNI. ${ }^{19}$

Dalam Undang-undang itu sudah ditetapkan bahwa peranan dan kedudukan TNI sebagai otoritas operasional pengerahan kekuatan dan gelar pasukan TNI berada dibawah presiden langsung, sedangkan ketentuan administrasi TNI berada dibawah Kemhan. Jadi, bagi TNI apa yang sedang dirumuskan Kemhan mengenai keamanan dan pertahanan nasional sudah tepat khususnya mengenai peran dan fungsi masingmasing departemen dalam pengelolaan pertahanan dan keamanan nasional baik secara langsung maupun tidak langsung. ${ }^{20}$

Tentang kemungkinan TNI dibawah Kemhan sebagai pemegang otoritas politik di sektor pertahanan. Selama ini TNI telah menjalankan peran dan fungsinya sesuai uandang-undang berlaku. Meski begitu, TNI menyerahkan sepenuhnya keputusan politik pemerintah mengenai kedudukan, peran dan fungsi

19 Mabes TNI, Eksistensi TNI Di Dalam RUU Kamnas, Rapat Tanggal 20 Oktober 2012.

20 Ibid, Mabes TNI, Eksistensi TNI Di Dalam RUU Kamnas, Rapat Tanggal 20 Oktober 2012.
TNI dalam Rancangan Undang-undang Kamnas. ${ }^{21}$

Kemhan membahas draft Rancangan Undang-undang Kamnas dengan instansi terkait, seperti Departemen Dalam Negeri, Departemen Luar Negeri, serta Departemen Hukum dan HakAsasi Manusia. Dirjen Strategi Pertahanan (Strahan) Dephan, Rancangan Undangundang Kamnas difokuskan pada pengaturan aktor keamanan nasional. Untuk Polri, dalam draft Rancangan Undang-undang Kamnas tidak disebutkan harus berada dibawah departemen apa. Sebab, itu terserah presiden dan DPR. Yang pasti, Depdagri adalah pemegang otoritas politik dan keamanan dalam negeri. Demikian juga dengan kedudukan TNI, yang jelas sebagai otoritas operasional dan Dephan sebagai pemegang otoritas pertahanan didalam rancangan undangundang keamanan nasional. ${ }^{22}$

Thomas Hobbes dan Maslow melihathukumsebagai kebutuhan dasarbagi keamanan individu.Berdasarkan teori diatas bahwa keamanan nasional merupakan bagian dari kebutuhan individu sebagai warga Negara, dalam rangka menjamin keamanan dan kesejahteraan warga negaranya. Dengan adanya pembentukan peraturan perundang-undangan melalui rancangan undang-undang keamanan nasional, ruu kamnas perlu disahkan yang bertujuan memenuhi kebutuhan warga Negara Indonesia khususnya didalam sektor keamanan nasional.

2. Politik hukum yang di gunakan dalam kaitannya tentang peranan dan kedudukan TNI di dalam Rancangan Undang-undang Keamanan Nasional (Pembahasan Pada Tanggal 16 Oktober 2012).

Adapun politik hukum yang terkandung dalam penyusunan rancangan

21 Ibid, Mabes TNI, Eksistensi TNI Di Dalam RUU Kamnas, Rapat Tanggal 20 Oktober 2012.

22 Ibid, Mabes TNI, Eksistensi TNI Di Dalam RUU Kamnas, Rapat Tanggal 20 Oktober 2012. 
undang-undang keamanan nasional diantaranya adalah

1) Tujuan nasional bangsa Indonesia sebagaimana diamanatkan dalam pembukaan Undang-undang Dasar Negara Republik Indonesia 1945 adalah untuk melindungi segenap bangsa Indonesia dan seluruh tumpah darah Indonesia dan untuk memajukan kesejahteraan umum, mencerdaskan kehidupan bangsa, dan ikut melaksanakan ketertiban dunia yang berdasarkan kemerdekaan, perdamaian abadi, dan keadilan sosial. ${ }^{23}$

2) Dalam rangka mewujudkan tujuan nasional, pemerintah Indonesia pada dasarnya mengelola keamanan dan kesejahteraan nasional yang dilaksanakan melalui pembangunan nasional secara bertahap, dan berlanjut. ${ }^{24}$

3) keamanan nasional merupakan syarat mutlak untuk keberlangsungan eksistensi bangsa dan Negara Indonesia. ${ }^{25}$

4) Keempat, sejak berdirinya Negara kesatuan Republik Indonesia pada tanggal 17 Agustus 1945, Negara dan bangsa Indonesia menghadapi berbagai ancaman yang dapat membahayakan kepentingan nasional. ${ }^{26}$

5) Kelima, letak dan kondisi geografis Indonesia sebagai Negara kepulauan serta kemajukan bangsa Indonesia yang tersebar diseluruh wilayah Republik Indonesia dihadapkan kepada lingkungan strategis dan arus globalisasi yang ditandai dengan kemajuan ilmu pengetahuan,

23 Hasil Rapat 16 Oktober 2012, Rancangan Undangundang Keamanan Nasional, Komisi III DPR RI, hlm 2.

24 Ibid, Hasil Rapat 16 Oktober 2012, Rancangan Undangundang Keamanan Nasional, Komisi III DPR RI, hlm.3.

25 Ibid, Hasil Rapat 16 Oktober 2012, Rancangan Undangundang Keamanan Nasional, Komisi III DPR RI, hlm. 4.

26 Ibid, Hasil Rapat 16 Oktober 2012, Rancangan Undangundang Keamanan Nasional, Komisi III DPR RI, hlm. 5 . teknologi, komunikasi, informasi, dan transportasi yang dapat berdampak positif dan negative terhadap kepentingan nasional. ${ }^{27}$

6) Dalam mewujudkan stabilitas keamanan nasional pengelolaan keamanan nasional harus dilaksanakan oleh seluruh perangkat Negara dan komponen masyarakat melalui suatu pola penanggulangan ancaman secara terpadu, cepat, tepat, tuntas, dan terkordinasi. ${ }^{28}$

Diantara beberapa politik hukum yang terkandung didalam penyusunan rancangan undang-undang keamanan nasional mempunyai tujuan utama yaitu mewujudkan kondisi aman bangsa dan Negara kesatuan Republik Indonesia secara fisik dan psikis setiap individu warga Negara, masyarakat, pemerintah dan Negara, dalam rangka melindungi kepentingan nasional.

\section{PENUTUP}

\section{Kesimpulan}

Berdasarkan hasil penelitian yang telah dilakukan, penulis menarik kesimpulan bahwa:

1. Hakikat keamanan nasional merupakan segala upaya secara cepat, bertahap dan terpadu dengan memberdayakan seluruh kekuatan nasional untuk menciptakan stabilitas keamanan melalui suatu sistem keamanan nasional, tujuan keamanan nasional bertujuan untuk mewujudkan kondisi aman bangsa dan Negara kesatuan Republik Indonesia secara fisik dan psikis setiap individu warga Negara, masyarakat, pemerintah dan Negara, dalam rangka untuk melindungi kepentingan nasional, dan fungsi penyelenggaraan

27 Ibid, Hasil Rapat 16 Oktober 2012, Rancangan Undangundang Keamanan Nasional, Komisi III DPR RI, hIm. 6.

28 Ibid, Hasil Rapat 16 Oktober 2012, Rancangan Undangundang Keamanan Nasional, Komisi III DPR RI, hIm. 6. 
keamanan nasional adalah untuk: Membangun, memelihara, dan mengembangkan sistem keamanan nasional secara menyeluruh, terpadu, dan terarah, mewujudkan seluruh wilayah yurisdiksi nasional sebagai suatu kesatuan keamanan nasional, memelihara dan meningkatkan stabilitas keamanan nasional melalui tahapan pencegahan dini, peringatan dini, penindakan dini, penanggulangan, dan pemulihan menunjang dan mendukung terwujudnya perdamaian dan keamanan regional serta internasional.

Peranan dan kedudukan TNI didalam rancangan undangundang keamanan nasional yaitu, tetap berpedoman pada Undang-undang No. 34 Tahun 2004 tentang TNI dengan tidak merubah tugas pokok dan fungsi TNI dan juga tidak berpengaruh pada hal-hal lainnya.

2. Politik hukum yang terkandung didalam penyusunan rancangan undang-undang keamanan nasional mempunyai tujuan utama yaitu mewujudkan kondisi aman bangsa dan Negara kesatuan Republik Indonesia secara fisik dan psikis setiap individu warga Negara, masyarakat, pemerintah dan Negara, dalam rangka melindungi kepentingan nasional. Keamanan juga dipahami sebagai upaya negara untuk mencegah perang, melalui strategi pembangunan pertahanan, membangun kemampuan penangkal (deterrent power). Dengan adanya politik hukum didalam rancangan undangundang keamanan nasional, dapat memberikan sebuah konsep terkait dengan reformasi sektor keamanan dan menata ulang system keamanan nasional, reformasi sektor keamanan (Security Sector Reform) SSR, merupakan sebuah konsep yang masih baru dalam terminologi sosial-politik dan menjadi salah satu isu sentral dalam konteks good governance. Meskipun tidak ada definisi tunggal yang diterima secara global, namun SSR umumnya dipahami mengacu pada proses mereformasi atau membangun kembali sektor keamanan suatu negara. Sebagai respons atas ketidakmampuan sektor ini memberikan keamanan kepada negara dan rakyat. Dalam beberapa kasus, sektor keamanan itu sendiri dapat menjadi sumber ketidakamanan bagi masyarakat akibat kebijakan yang diskriminatif dan penyalahgunaan kewenangan oleh otoritas keamanan.

\section{Saran}

1. Apabila rancangan undangundang tersebut disahkan menjadi undang-undang keamanan nasional, peranan dan kedudukan TNI tidak bertentangan dengan tugas pokok dan fungsi TNI didalam Undang-undang No.34 Tahun 2004 tentang TNI maupun Undang-undang lain yang terkait dengan $\mathrm{TNI}$, dengan diundangkannya Undang-undang keamanan nasional maka TNI harus lebih profesional dan solid dalam menajalankan tugasnya menjaga dan memlihara pertahanan dan keamanan Negara kasatuan replublik Indonesia. Apabila kita sepakat dengan pemahaman yang sama tentang pentingnya sebuah kerangka Konsep Keamanan Nasional yang komprehensif, maka akan mudah bagi kita untuk sependapat kalau kita memang membutuhkan sebuah Undang- 
undang Keamanan nasional.

2. Dalam pembentukan rancangan undang-undang keamanan nasional harus tetap memperhatikan tiga syarat keabsahan: Keabsahan filosofis (filosofische gelding), yakni antara Undang-undang Keamanan Nasional dengan sistem nilai filsafat dan ideologi kenegaraan harus sesuai. Keabsahan Sosiologis (sosiologische gelding), antara Undang-undang
Keamanan Nasional dengan sistem nilai bangsa Indonesia yang sangat majemuk, baik dari aspek ras, etnik, suku agama maupun golongan juga harus disesuaikan. Serta Keabsahan Yuridis (yuridische gelding), kesesuaian dan konsistensi antara norma yang tercantum dalam Undang-undang Keamanan Nasional dengan keseluruhan sistem hukum positif di Indonesia.

\section{DAFTAR PUSTAKA}

- Buku-Buku:

Endriantono Sutanto, Jati Diri TNI, Mabes TNI, Cilangkap Jakarta

Faisal Farhan, Skripsi tentang "Tindak Pidana Disersi Ditinjau Dari Perspektif Hukum Pidana Militer", Universitas Pasundan Fakultas Hukum, Bandung 2011

Hasil Rapat 16 Oktober 2012, Rancngan Undang-undang Keamanan Nasional, Komisi III DPR RI

Jendral TNI Endriartono Sutarto, Kewajiban Prajurit Mengabdi Kepada Bangsa, Pusat Penerangan TNI, Desember 2005

Jurnal Mabes TNI, Efektivitas Undang-undang TNI \& POLRI Di Indonesia, Mabes TNI, Cilangkap Jakarta

Peter Mahmud Marzuki, 2010, Penelitian Hukum, Kencana, Jakarta

Syamsul Maarif, 2011, Militer Dalam Parlemen 1960-2004, Prenada

Undang-undang No. 34 Tahun 2004 Tentang TNI, Fungsi dan Tujuan TNI, Mabes TNI, Jakarta

- Peraturan perundang-undangan:

Undang-undang Nomor 34 Tahun 2004 Tentang Tentara Nasional Indonesia

- Website :

www.kompas.com

www.google.com 